\title{
Electrooxidation of tannery wastewater with continuous flow system: Role of electrode materials
}

\author{
Tran Tan Tien, Tran Le Luu ${ }^{\dagger}$ \\ Department of Mechatronics and Sensor Systems Technology, Vietnamese German University 820000, Viet Nam
}

\begin{abstract}
Tannery wastewater is known to contain high concentrations of organic compounds, pathogens, and other toxic inorganic elements such as heavy metals, nitrogen, sulfur, etc. Biological methods such as aerobic and anaerobic processes are unsuitable for tannery wastewater treatment due to its high salinity, and electrochemical oxidation offers a promising method to solve this problem. In this study, raw tannery wastewater treatment using DSA ${ }^{\circledR} \mathrm{Ti} / \mathrm{RuO}_{2}, \mathrm{Ti} / \mathrm{IrO}_{2}$ and $\mathrm{Ti} / \mathrm{BDD}$ electrodes with continuous flow systems was examined. Effects of current densities and electrolysis times were investigated, to evaluate the process performance and energy consumption. The results showed that a Ti/BDD electrode is able to reach higher treatment efficiency than $\mathrm{Ti} / \mathrm{IrO}_{2}$, and $\mathrm{Ti} / \mathrm{RuO}_{2}$ electrodes across all parameters, excluding Total Nitrogen. The main mechanism of tannery wastewater oxidation at a Ti/BDD electrode is based on direct oxidation on the electrode surface combined with the generation of oxidants such as ${ }^{\circ} \mathrm{OH}$ and $\mathrm{Cl}_{2}$, while at $\mathrm{DSA} \otimes \mathrm{Ti} / \mathrm{RuO}_{2}$ and $\mathrm{Ti} / \mathrm{IrO}_{2}$ electrodes, the oxidation mechanisms are based on the generation of chlorine. After treatment, the effluents can be discharged to the environment after 6-12 h of electrolysis. Electrooxidation thus offers a promising method for removing the nutrients and non-biodegradable organic compounds in tannery wastewater.
\end{abstract}

Keywords: Electrooxidation, Tannery wastewater, Ti/BDD, Ti//rO $2, \mathrm{Ti} / \mathrm{RuO}_{2}$

\section{Introduction}

The tanning industry contributes a great deal to Vietnam's current socio-economic development, supplying materials for other industries, and creating stable jobs for thousands of workers [1]. Besides economic development, the environmental issues associated with industrial tanning waste are also a top concern for many enterprises. The specialty of the tanning industry is the use of raw materials such as buffalo, cow, goat, and sheep hides with the production using a large amount of water and a variety of chemicals [2]. Discharged tannery waste contains high concentrations of pollutants, solid wastes, and toxic gases. Tanning wastewater comprises many chemicals, such as dyes, organic solvents, total solids (TS), suspended solids (SS), color, ammonium, oil, high salt content and pathogenic microorganisms [3-10]. The toxic components in the tannery wastewater affect the surrounding environment. Tannery wastewater pollutants have exceeded the Vietnamese discharge standards of industrial wastewater QCVN 40:2011/BTNMT on many occasions. At the moment, most tannery enterprises in Vietnam either do not have adequate sewage treat- ment systems or discharge wastewaters directly into the general drainage system of the community [1]. The environmental pollution from the tanning industry is thus very serious, and an effective solution is urgently required. High salinity wastewater treatment by a biological method such as an activated sludge process often results in low Chemical Oxygen Demand (COD) removal efficiency, due to the inhibited growth of microorganisms by the inorganic salts if salinity is higher than 1\% [11-14]. Removing salts from tannery wastewater is therefore a prerequisite for biological treatment; however, this is not an easy task. Advanced oxidation processes (AOPs) are known for the decomposition of organic compounds by the free hydroxyl radicals $\left({ }^{\circ} \mathrm{OH}\right)$, due to their high oxidation potential and mineralization of almost any organic molecule in wastewater, to produce $\mathrm{CO}_{2}$ and inorganic ions in the output product [15-17]. Among the AOPs, electrochemical oxidation has been successfully investigated for the removal of toxic organic compounds under the activity of direct and indirect oxidants as ${ }^{\circ} \mathrm{OH}$ radical, $\mathrm{H}_{2} \mathrm{O}_{2}, \mathrm{O}_{3}$ [18]. In addition, pollutant treatment by electrochemical oxidation has achieved high efficiency when wastewater contains a high chloride concentration, by the gen-
This is an Open Access article distributed under the terms of the Creative Commons Attribution Non-Commercial License (http://creativecommons.org/licenses/by-nc/3.0/) which permits unrestricted non-commercial use, distribution, and reproduction in any medium, provided the original work is properly cited.

Copyright (C) 2020 Korean Society of Environmental Engineers
Received October 1, 2018 Accepted May 8, 2019

${ }^{\dagger}$ Corresponding author

Email: luu.tl@vgu.edu.vn

Tel: +84-0968913909

ORCID: 0000-0001-5277-716X 
eration of chlorine [19]. Electrochemical wastewater treatment is now of increasingly interest because it has advantages such as simple equipment, high capacity for medium and small scale use, low initial investment, easily automated electrical speed control, reduced chemical reagent, and is an environmentally friendly "green" technology: low generation of secondary chemicals, high selectivity [20]. There are many electrodes which can be used as anode materials for electrochemical water treatment [21]. Among these electrodes, Dimensional Stable Anode (DSA) and Boron Doped Diamond (BDD) have proven the most superior due to their excellent properties in wastewater treatment [22-24]. In this study, primary tannery wastewater with high levels of salinity and organic pollutants was treated by electrochemical methods in the laboratory using commercially available $\mathrm{DSA}{ }^{\circledR} \mathrm{Ti} / \mathrm{RuO}_{2}$, $\mathrm{Ti} / \mathrm{IrO}_{2}$ and $\mathrm{Ti} / \mathrm{BDD}$ electrodes. The influence of current densities and electrolysis times were assessed according to level of pollutant removal and energy efficiency. The treatment efficiencies were evaluated using COD, Biological Oxygen Demand (BOD ${ }_{5}$ ), Total Organic Carbon (TOC), Total Nitrogen (TN), colour. As far as the literature review, this is the first time the treatment of raw tannery wastewater using DSA compared with BDD electrode in the continuous flow system has been reported with multiparameters. This research suggests a platform for proposing appropriate and feasible technology for treating raw tannery wastewater by electrooxidation.

\section{Materials and Methods}

\subsection{Experimental Setup}

The experimental setup for the study of tannery wastewater treatment using electrochemical oxidation is shown in Fig. 1. The experiments were performed at room temperature, in a conventional single compartment flow cell with three electrodes, using a computer-controlled potentiostat (PARSTAT 2273A, Princeton Applied Research, USA) and power supply (UDP 1501, Unicorn, South Korea) to maintain a constant current. The applied potential was from $0-3 \mathrm{~V}$ vs. Ag/AgCl. Scan rate was $5 \mathrm{mV} / \mathrm{s}$. The change of current vs voltage was recorded as linear sweep voltammery to monitor the in situ electrochemical process at the electrode surface. The main equipment in the model included: a $7 \mathrm{~cm} \mathrm{x}$ $6 \mathrm{~cm} \times 6.5 \mathrm{~cm}$ input water tank with effective volume of 168 $\mathrm{mL}$; a $3.8 \mathrm{~cm} \times 3.8 \mathrm{~cm} \times 4.5 \mathrm{~cm}$ main reaction tank with a volume of $50 \mathrm{~mL}$. The flow of tannery wastewater was controlled by a peristaltic pump with a volumetric flow of $5 \mathrm{~mL} / \mathrm{min}$. Ti/ $\mathrm{RuO}_{2}$, $\mathrm{Ti} / \mathrm{IrO}_{2}$ and $\mathrm{Ti} / \mathrm{BDD}$ (Permelec De Nora, Japan) were selected as the working electrodes (anode), Pt (Samsung Chemicals, South Korea) as the counter electrode (cathode), and $\mathrm{Ag} / \mathrm{AgCl}$ (in saturated $\mathrm{KCl})$ as the reference electrode. The size of each electrode was $3 \mathrm{~cm} \times 2 \mathrm{~cm}$, and the distance between anode and cathode was $3 \mathrm{~cm}$. A magnetic agitator was used to control the mass transfer between the wastewater and electrode surface. Tannery wastewater was collected at the Dang Tu Ky leather factory in Binh Tan District, Ho Chi Minh City, Viet Nam. When studying the effect of a changing parameter, the other parameters were held constant. The difference optimimum operation parameters were collected in order to achieve high electrochemical degradation efficiency. To evaluate the effects of current density during the electrochemical oxidation of tannery

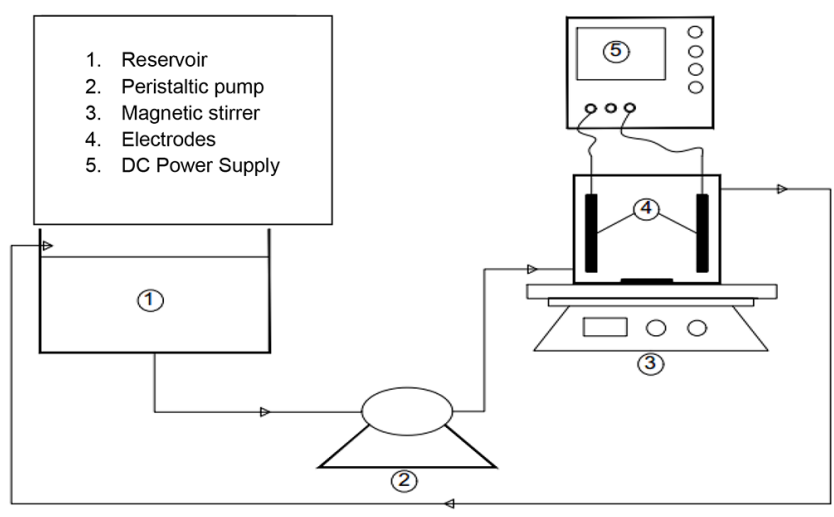

Fig. 1. The experimental setup.

wastewater, the current density was varied between $17 \mathrm{~mA} / \mathrm{cm}^{2}$ and $80 \mathrm{~mA} / \mathrm{cm}^{2}$. The mixing speed was set at $400 \mathrm{rpm}$ with a magnetic stirrer. The electrolysis time was set at seven different time periods from $1 \mathrm{~h}$ to $12 \mathrm{~h}$. The electrochemical characterizations of the metal oxide electrodes were examined using cyclic voltammetry (CV) measurements. The properties of the input tannery wastewater are shown in Table S1 (in Supporting Information), in which contamination levels can be seen to be much higher than the current Vietnamese Discharge Standard Regulation QCVN 40:2011/BTNMT.

\subsection{Wastewater Analysis}

All of the experiments were performed at room temperature, and analysis followed the Standard Method for the Examination of Water and Wastewater (APHA, USA) [25]. At regular time intervals, wastewater samples were withdrawn and collected in a beaker for further analysis. $\mathrm{pH}$, and colour were measured using a Metrohm 900 multimeter, Switzerland. COD was measured using a Lovibond RD125 Thermoreactor (England) in Closed Reflux Titrimetric Method. $\mathrm{BOD}_{5}$ were measured using a Lovibond® BD 600, England. A nitrification inhibitor (Formula 2533 ${ }^{\mathrm{TM}}$, TCMP, 35 g, Hach, USA) was added to the water sample before measurement BOD to hinders the oxidation of ammonia nitrogen, which supplies the nitrogenous BOD, and so ensure the BOD value was not affected by nitrogen bacteria and totally inner. TOC and TN were measured using a TOC Shimadzu 00936, Japan. Total $\mathrm{Cl}^{-}$was measured by using Ion Chromatography (Metrohm IC 883, Switzerland).

\subsection{Energy Consumption}

Energy consumption during processing was calculated based on the decrease of COD using the following formula [26, 27]:

$$
E C=\frac{t V C / S_{v} / 1 \times 10^{3}}{\triangle C O D / 1 \times 10^{6}}
$$

Where: $E C$ is the power consumption (kWh/kgCOD); $t$ is the time of electrolysis (h); $V$ is the mean voltage during the electrolysis (V); $C$ is the current density (A); $S_{V}$ is the volume of electrolyte solution (l) and $\triangle C O D$ is the concentration of COD removed during time $\mathrm{t}(\mathrm{mg} / \mathrm{L})$. 


\section{Results and Discussion}

\subsection{COD Removal}

Fig. 2 shows the COD removal efficiencies of the $\mathrm{Ti} / \mathrm{RuO}_{2}, \mathrm{Ti} / \mathrm{IrO}_{2}$ and $\mathrm{Ti} / \mathrm{BDD}$ electrodes at different current densities and electrolysis times. In general, with all three electrodes, the COD removal efficiencies increased as the current densities increased. As shown in Fig. 2(a) with the $\mathrm{Ti} / \mathrm{RuO}_{2}$ electrode, the COD removal yield of the $\mathrm{Ti} / \mathrm{RuO}_{2}$ electrode at current density $80 \mathrm{~mA} / \mathrm{cm}^{2}$ after 12 $\mathrm{h}$ of treatment was $82 \%$. The corresponding COD of the effluent at that point was $768 \mathrm{mg} / \mathrm{L}$, indicating that tannery wastewater after treatment had not reached the Vietnamese discharge standard QCVN 40:2011/BTNMT. There was no significant difference in COD removal efficiencies between $50 \mathrm{~mA} / \mathrm{cm}^{2}$ and $80 \mathrm{~mA} / \mathrm{cm}^{2}$ after 6-12 h of electrolysis (only 3-5\%). In particular, after $6 \mathrm{~h}$ of electrolysis, the COD removal efficiencies were $55.24 \%, 70.34 \%$ and $70.57 \%$ at current densities $16.7 \mathrm{~mA} / \mathrm{cm}^{2}, 50 \mathrm{~mA} / \mathrm{cm}^{2}$ and $80 \mathrm{~mA} / \mathrm{cm}^{2}$, respectively. The COD removal efficiency of the $\mathrm{Ti} / \mathrm{RuO}_{2}$ electrodes in this study is comparable with the report of Panizza et al. [28] on a $\mathrm{Ti} / \mathrm{RuO}_{2}$ electrode, with removal efficiency
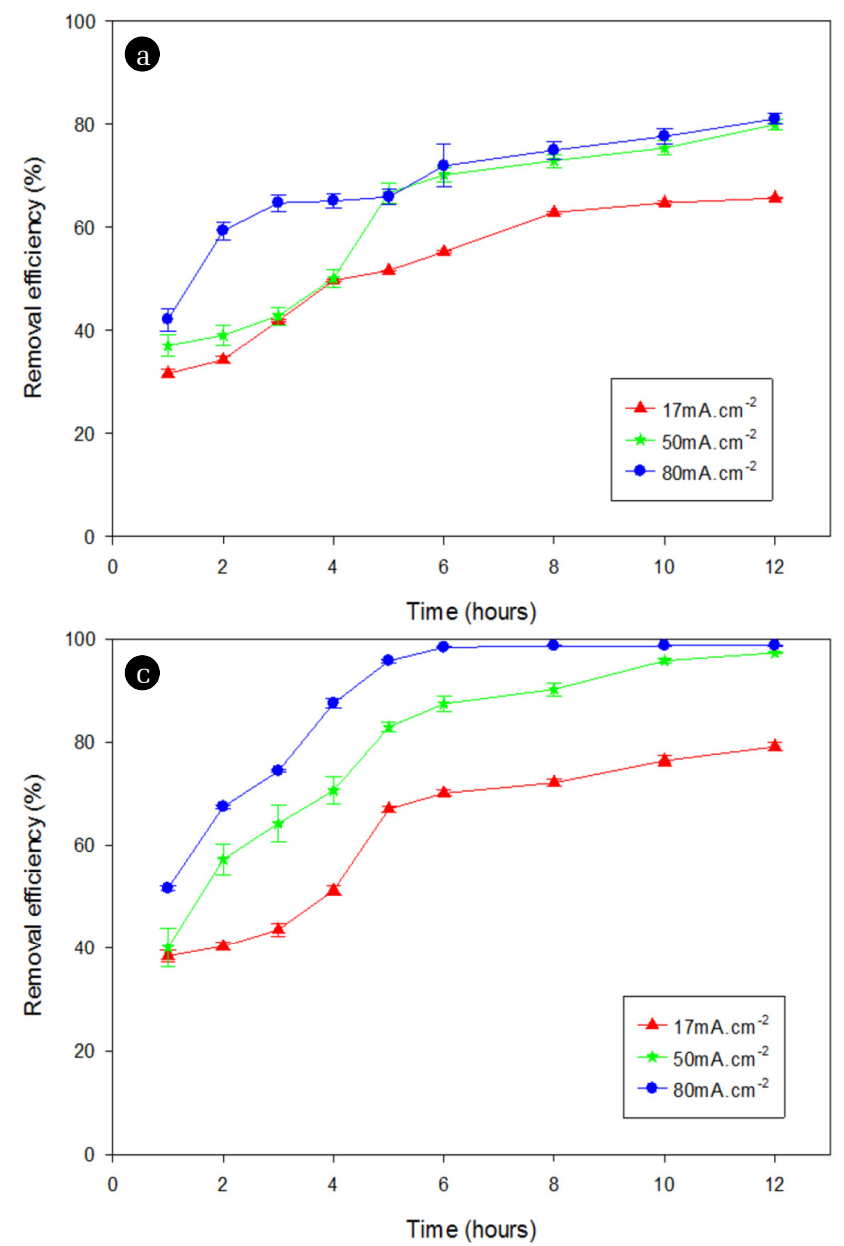

of $90 \%$ after $12 \mathrm{~h}$ of electrolysis at current density of $60 \mathrm{~mA} / \mathrm{cm}^{2}$ and input COD 2,100 mg/L. Kongjao et al. [29] showed that the COD removal efficiency of $\mathrm{Ti} / \mathrm{RuO}_{2}$ electrodes in tanning effluents with an input concentration of 17,240-17,860 mg/L, gave a high efficiency of $82 \%$ at current density $60.5 \mathrm{~mA} / \mathrm{cm}^{2}$ after $1 \mathrm{~h}$ of electrolysis. The main mechanism of pollutant treatment using a $\mathrm{Ti} / \mathrm{RuO}_{2}$ electrode is based on indirect electrolysis, the direct oxidation on the electrode surface is negligible. Since the salinity in tannery was about $5,000 \mathrm{mg} / \mathrm{L}$, COD is eliminated by indirectly electrolyzing chloride ions at $\mathrm{Ti} / \mathrm{RuO}_{2}$ according to the following equations [28]:

$$
\begin{gathered}
2 \mathrm{Cl}^{-} \rightarrow \mathrm{Cl}_{2(\text { aq })}+2 \mathrm{e}^{-} \\
\mathrm{Cl}_{2(\mathrm{aq})}+\mathrm{H}_{2} \mathrm{O} \rightarrow \mathrm{HClO}+\mathrm{Cl}^{-}+\mathrm{H}^{+}
\end{gathered}
$$

Organic compound $+\mathrm{Cl}_{2} \rightarrow$ oxidation product $+2 \mathrm{Cl}^{-}$

In another aspect, the COD treatment efficiency of $\mathrm{Ti} / \mathrm{IrO}_{2}$ electrodes in tannery wastewater is shown in Fig. 2(b). The results show that COD removal efficiency of $\mathrm{Ti} / \mathrm{IrO}_{2}$ electrode was significantly
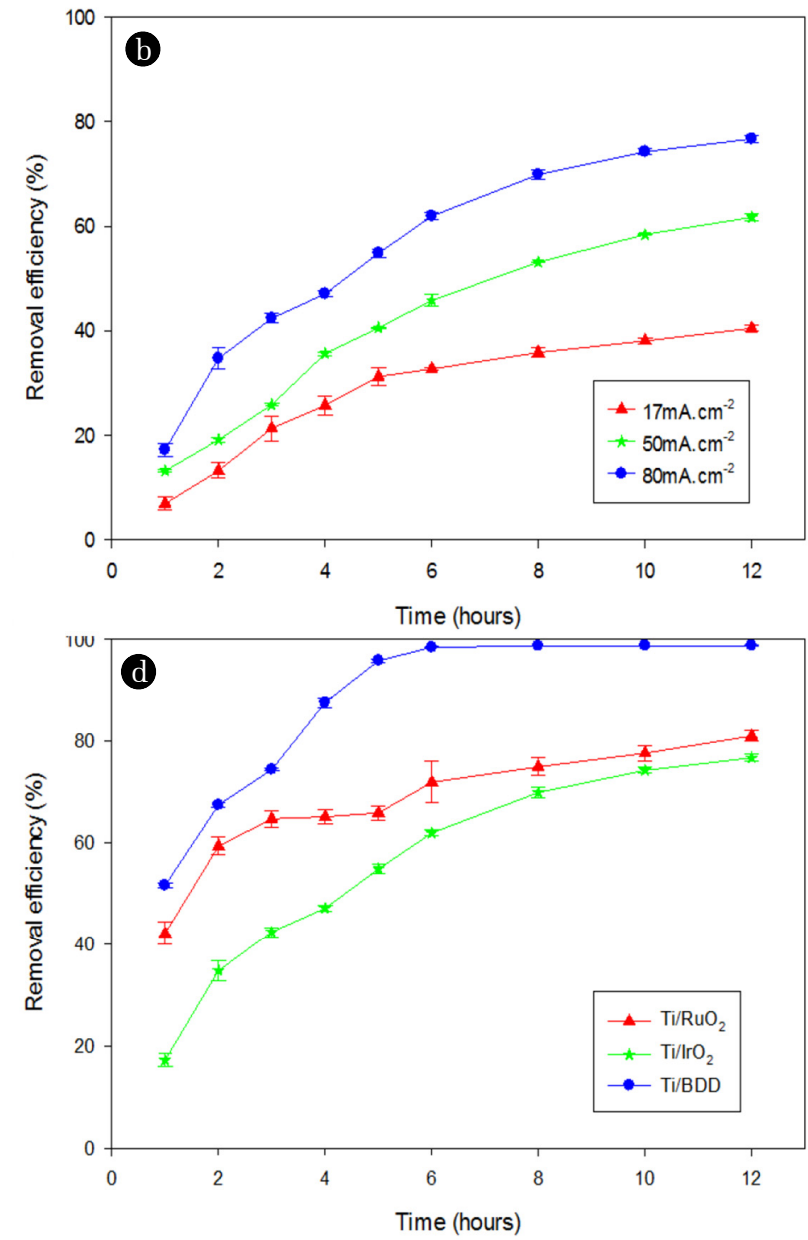

Fig. 2. COD removal efficiencies of (a) $\mathrm{Ti}_{\mathrm{RuO}}$, (b) $\mathrm{Ti} / \mathrm{IrO}_{2}$, (c) $\mathrm{Ti} / \mathrm{BDD}$ electrodes at different current densities and (d) all electrodes at current density $80 \mathrm{~mA} / \mathrm{cm}^{2}$. 
lower than a $\mathrm{Ti} / \mathrm{RuO}_{2}$ electrode. This is explained by the fact that the pollutant treatment mechanism on the $\mathrm{Ti} / \mathrm{IrO}_{2}$ electrode is similar to the $\mathrm{Ti} / \mathrm{RuO}_{2}$ electrode, which is based on indirect oxidation due to the formation of the chlorine compound. However, chlorine evolution efficiency on the $\mathrm{Ti} / \mathrm{IrO}_{2}$ electrode is lower than the $\mathrm{Ti} / \mathrm{RuO}_{2}$ electrode [30]. The COD concentration in effluent after $12 \mathrm{~h}$ of electrolysis was $933 \mathrm{mg} / \mathrm{L}$, and had not achieved the Vietnamese discharge standard QCVN 40:2011/BTNMT. In the earlier study of Szpyrkowic et al. [31], which used a Ti/Pt/Ir electrode on primary tanning effluent, the COD treatment efficiency was $60 \%$ after 40 min of electrolysis. However in that study, a positive electrode area was $100 \mathrm{~cm}^{2}$ (17 times greater than the electrode in the present study, and was used to treat a $670 \mathrm{~mL}$ volume of wastewater). This suggests that the ratio between electrode surface area and volume of treated wastewater has a great influence on process efficiency.

As shown in Fig. 2(c) using a Ti/BDD electrode, the COD removal efficiency of the Ti/BDD electrode was relatively high, corresponding to $88.82 \%$ and $98.45 \%$ at $50 \mathrm{~mA} / \mathrm{cm}^{2}$ and $80 \mathrm{~mA} / \mathrm{cm}^{2}$ after $6 \mathrm{~h}$ of electrolysis, respectively. After $6 \mathrm{~h}$ of treatment at a current density of $80 \mathrm{~mA} / \mathrm{cm}^{2}$, COD post-treatment concentration was 64 $\mathrm{mg} / \mathrm{L}$, and reached Vietnamese discharge standard QCVN 40:2011/BTNMT. At current density $50 \mathrm{~mA} / \mathrm{cm}^{2}$ after $12 \mathrm{~h}$ of electrolysis, COD concentration of the effluent was $103 \mathrm{mg} / \mathrm{L}$ and also reached the Vietnamese discharge standard QCVN 40:2011/BTNMT. Compared with $\mathrm{Ti} / \mathrm{RuO}_{2}$ and $\mathrm{Ti} / \mathrm{IrO}_{2}$ electrodes, the COD removal efficiency of the Ti/BDD electrode was highest. As shown in Fig. 2(d), with the comparison of three electrodes, at current density $80 \mathrm{~mA} / \mathrm{cm}^{2}$, and after $6 \mathrm{~h}$ of electrolysis, the COD removal efficiency of the Ti/BDD electrode was $98.45 \%$, while at the $\mathrm{Ti} / \mathrm{RuO}_{2}$ electrode efficiency was $70.15 \%$ and the $\mathrm{Ti} / \mathrm{IrO}_{2}$ electrode efficiency only $62.01 \%$. The results also suggest that $6 \mathrm{~h}$ is the most suitable electrolysis time for all 3 electrodes. The high COD removal efficiency of the Ti/BDD electrode is attributed to the simultaneous oxidation on the electrode surface by direct and indirect oxidation [32]. Direct oxidation on the surface of the Ti/BDD electrodes is accomplished by the first step of releasing water molecules, forming ${ }^{\circ} \mathrm{OH}$ as per Eq. (5). Then, the oxidation of organic compounds is made via the newly formed ${ }^{\circ} \mathrm{OH}$ radical as per Eq. (6) [33, 34].

$$
\begin{gathered}
\mathrm{BDD}+\mathrm{H}_{2} \mathrm{O} \rightarrow \mathrm{BDD}\left({ }^{\circ} \mathrm{OH}\right)+\mathrm{H}^{+}+\mathrm{e}^{-} \\
\mathrm{BDD}\left({ }^{\circ} \mathrm{OH}\right)+\mathrm{R} \rightarrow \mathrm{BDD}+\mathrm{mCO}_{2}+\mathrm{nH}_{2} \mathrm{O}+\mathrm{H}^{+}+\mathrm{e}^{-}
\end{gathered}
$$

On the other hand, indirect electrolysis in the presence of chloride ions in wastewater also forms chlorine according to Eq. (4); $\mathrm{Cl}_{2 \text { (aq) }}$ is then rapidly involved in hydrolysis forming HClO by Eq. (5), which has the effect of decomposing organic compounds as per Eq. (6) [35]. This mechanism is similar to the mechanism of chlorine evolution at $\mathrm{Ti} / \mathrm{RuO}_{2}$ and $\mathrm{Ti} / \mathrm{IOO}_{2}$ electrodes. In addition, $\mathrm{HClO}$ can be oxidized on the surface of the BDD electrode to form $\mathrm{ClO}_{3}^{-}, \mathrm{ClO}_{4}^{-}$, and this can reduce the chlorine smell during the reaction [32]. The higher the current density applied to Ti/BDD electrode, the higher the COD removal efficiency. This is explained by the fact that increasing the electrical current increases oxidant generation [36]. Beside ${ }^{\circ} \mathrm{OH}$, chlorine and oxygen evolution as per Eq. (9), $\mathrm{H}_{2} \mathrm{O}_{2}$ is produced by reaction of ${ }^{\circ} \mathrm{OH}$ radicals as per Eq. (10); $\mathrm{O}_{3}$ will be formed by reaction of ${ }^{\circ} \mathrm{OH}$ radical and $\mathrm{H}_{2} \mathrm{O}$ as per Eq. (11). Then $\mathrm{O}_{3}$ and $\mathrm{H}_{2} \mathrm{O}_{2}$ will also participate in organic decomposition to increase process efficiency [37]. Ti/BDD electrode is quite effective at COD removal in tannery wastewater. Only the COD of effluent at theTi/BDD electrode satisfied Vietnamese discharge standard QCVN 40:2011/BTNMT after $6 \mathrm{~h}$ of electrolysis at current density $80 \mathrm{~mA} / \mathrm{cm}^{2}$. The direct oxidation and indirect oxidation on the surface of the Ti/BDD electrode produced strong oxidizing radicals that could destroy organic compounds.

$$
\begin{gathered}
\mathrm{BDD}\left({ }^{\circ} \mathrm{OH}\right) \rightarrow \mathrm{BDD}+1 / 2 \mathrm{O}_{2}+\mathrm{H}^{+}+\mathrm{e}^{-} \\
2 \mathrm{BDD}\left({ }^{\circ} \mathrm{OH}\right) \rightarrow 2 \mathrm{BDD}+\mathrm{H}_{2} \mathrm{O}_{2} \\
\mathrm{BDD}\left({ }^{\circ} \mathrm{OH}\right)+2 \mathrm{H}_{2} \mathrm{O} \rightarrow \mathrm{BDD}+\mathrm{O}_{3}+5 \mathrm{H}^{+}+5 \mathrm{e}^{-}
\end{gathered}
$$

\section{2. $\mathrm{BOD}_{5}$ Removal}

Fig. 3 shows the $\mathrm{BOD}_{5}$ treatment efficiency of $\mathrm{Ti} / \mathrm{RuO}_{2}, \mathrm{Ti} / \mathrm{IrO}_{2}$ and Ti/BDD electrodes at different current densities and electrolysis times. Unlike the variation in COD removal efficiency, the biodegradable organic matter in tannery wastewater is easily decomposed by electrochemical oxidation. At all three electrodes, $\mathrm{BOD}_{5}$ treatment efficiencies ranged from $88 \%$ to $99 \%$ throughout the process. As shown in Fig. 3(a), with $\mathrm{Ti} / \mathrm{RuO}_{2}$ electrodes, it took up to $12 \mathrm{~h}$ of electrolysis at current density $17 \mathrm{~mA} / \mathrm{cm}^{2}$, while it needed up to $8 \mathrm{~h}$ at current density $50 \mathrm{~mA} / \mathrm{cm}^{2}$ for $\mathrm{Ti} / \mathrm{IrO}_{2}$ electrodes, as shown in Fig. 3(b), to match with Vietnamese discharge standard. After $6 \mathrm{~h}$ of electrolysis at current density $17 \mathrm{~mA} / \mathrm{cm}^{2}$, the output $\mathrm{BOD}_{5}$ concentration of the $\mathrm{Ti} / \mathrm{BDD}$ electrode was $47 \mathrm{mg} / \mathrm{L}$, and reached the Vietnamese discharge standard as in Fig. 3(c). The effluent also could be discharged into the environment after $2 \mathrm{~h}$ of electrolysis at the current density of $80 \mathrm{~mA} / \mathrm{cm}^{2}$ by a Ti/BDD electrode. The $\mathrm{Ti} / \mathrm{BDD}$ electrode showed the highest $\mathrm{BOD}_{5}$ treatment efficiency, while the $\mathrm{Ti} / \mathrm{RuO}_{2}$ and $\mathrm{Ti} / \mathrm{IrO}_{2}$ were lower, as shown in Fig. $3(d)$. Increasing the current density had the effect of increasing the removal efficiency of biodegradable organic matter to a similar level as nonbiodegradable compound, as discussed in the previous section.

\subsection{Total Nitrogen Removal}

Fig. 4 shows the $\mathrm{TN}$ removal efficiencies of $\mathrm{Ti} / \mathrm{RuO}_{2}, \mathrm{Ti} / \mathrm{IrO}_{2}$ and $\mathrm{Ti} / \mathrm{BDD}$ electrodes at different current densities and electrolysis times. As shown in Fig. 4(a), the TN treatment efficiency of $\mathrm{Ti} / \mathrm{RuO}_{2}$ electrodes was very high. At a current density of $50 \mathrm{~mA} / \mathrm{cm}^{2}$, after $2 \mathrm{~h}$ of electrolysis, the TN removal efficiency was $90 \%$, and reached the Vietnamese discharge standard after $8 \mathrm{~h}$ of electrolysis. It is worth noting that after $1 \mathrm{~h}$ of electrolysis at current density $80 \mathrm{~mA} / \mathrm{cm}^{2}$, the TN treatment efficiency was $93.6 \%$, with output concentration $44.6 \mathrm{mg} / \mathrm{L}$ at the $\mathrm{Ti} / \mathrm{RuO}_{2}$ electrode. At later intervals, the TN removal efficiency remained relatively stable and only reached the Vietnamese discharge standard when the electrolysis time was increased to $6 \mathrm{~h}$. This showed that the potential for 

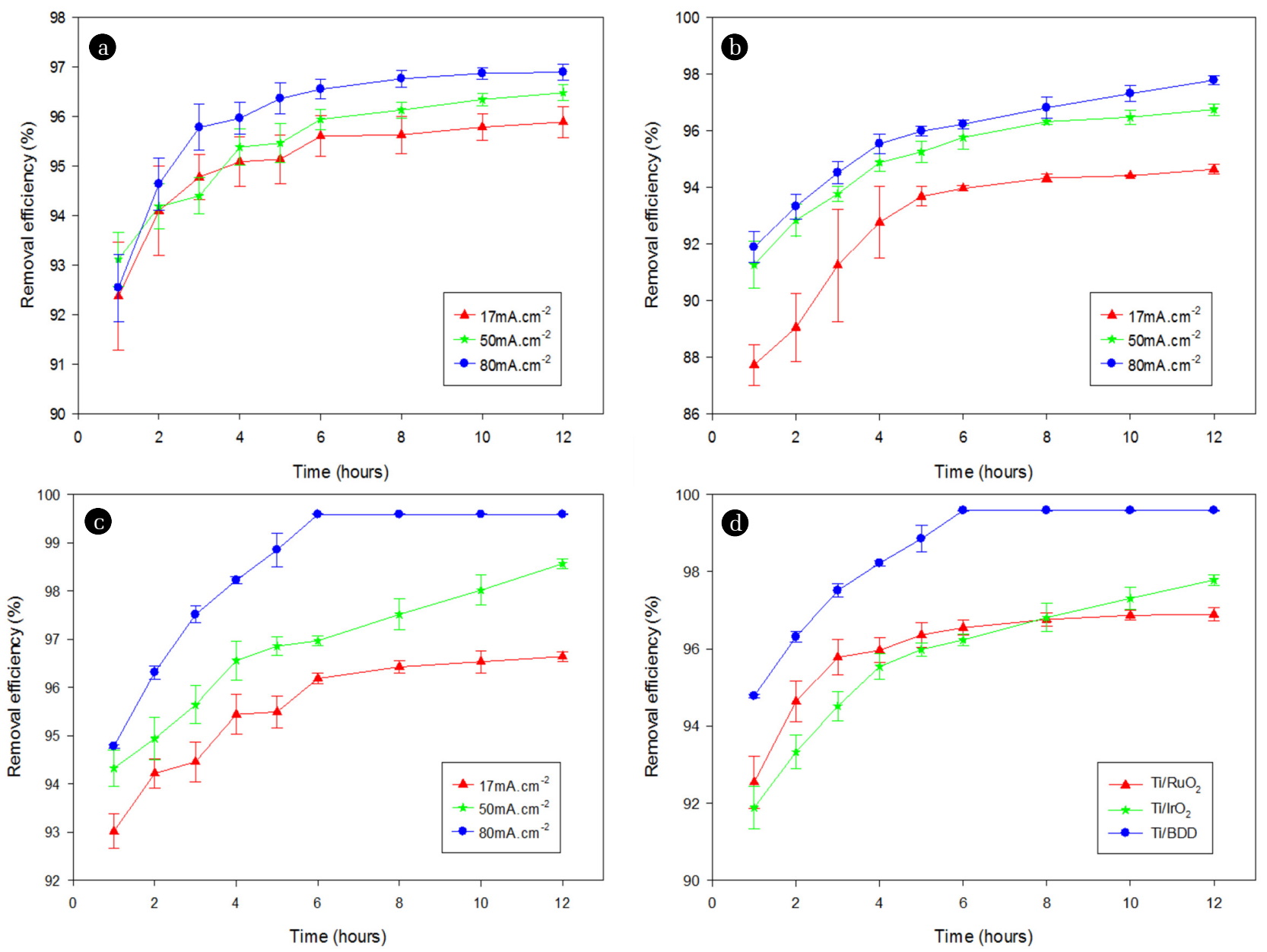

Fig. 3. $\mathrm{BOD}_{5}$ removal efficiency of (a) $\mathrm{Ti} / \mathrm{RuO}_{2}$, (b) $\mathrm{Ti} / \mathrm{IrO}_{2}$, (c) $\mathrm{Ti} / \mathrm{BDD}$ electrodes at different current densities and (d) all electrodes at current density $80 \mathrm{~mA} / \mathrm{cm}^{2}$.

nitrogen treatment by electrochemical oxidation at $\mathrm{Ti} / \mathrm{RuO}_{2}$ is greater than for other methods, such as physical, chemical and biological treatments which are still problematic. The main mechanism for decomposition of nitrogen compounds of the $\mathrm{Ti} / \mathrm{RuO}_{2}$ electrode can be attributed to indirect oxidation by chlorine/hypochlorite generation during electrochemical processes [38]. The HClO produced by chloride ions is involved in the decomposition of nitrogen compounds as per equations 12-14 or direct oxidation of $\mathrm{HClO}$ (as per Eq. (15)-(17)) [39-41]. The TN treatment efficiency of the $\mathrm{Ti} / \mathrm{RuO}_{2}$ electrode in this study is comparable with the report of Min et al. [42] who found that at a current density $40 \mathrm{~mA} / \mathrm{cm}^{2}$, after $30 \mathrm{~min}$ of electrolysis, TN removal efficiency was $75 \%$, with an input TN concentration $927 \mathrm{mg} / \mathrm{L}$. However, in that study, the authors used an electrode with a surface area of $279 \mathrm{~cm}^{2}$ and electrolyte volume 1,700 mL. This again demonstrates that the ratio between electrode surface area and volume of wastewater is important, as the larger the area of the electrode, the lower the electrolysis time, leading to a reduction in the amount of electricity consumption and higher performance.

$$
\begin{gathered}
\mathrm{HClO}+\mathrm{NH}_{4}^{+} \rightarrow \mathrm{NH}_{2} \mathrm{Cl}+\mathrm{H}_{2} \mathrm{O}+\mathrm{H}^{+} \\
\mathrm{HClO}+\mathrm{NH}_{2} \mathrm{Cl} \rightarrow \mathrm{NHCl}_{2}+\mathrm{H}_{2} \mathrm{O} \\
\mathrm{H}_{2} \mathrm{O}+\mathrm{NHCl}_{2} \rightarrow \mathrm{NOH}+2 \mathrm{H}^{+}+2 \mathrm{Cl}^{-} \\
\mathrm{NOH}+\mathrm{NHCl}_{2} \rightarrow \mathrm{N}_{2}+\mathrm{HOCl}+\mathrm{H}^{+}+\mathrm{Cl}^{-} \\
2 / 3 \mathrm{NH}_{4}^{+}+\mathrm{HClO} \rightarrow 1 / 3 \mathrm{~N}_{2}+\mathrm{H}_{2} \mathrm{O}+5 / 3 \mathrm{H}^{+}+\mathrm{Cl}^{-} \\
\mathrm{NH}_{4}^{+}+4 \mathrm{HOCl} \rightarrow \mathrm{NO}_{3}^{-}+\mathrm{H}_{2} \mathrm{O}+6 \mathrm{H}^{+}+4 \mathrm{Cl}^{-}
\end{gathered}
$$

Fig. 4(b) shows the $\mathrm{TN}$ removal efficiency of the $\mathrm{Ti} / \mathrm{IrO}_{2}$ electrode at different current densities and electrolysis times. After $6 \mathrm{~h}$ of electrolysis at a current density of $80 \mathrm{~mA} / \mathrm{cm}^{2}$, the TN treatment efficiency at the $\mathrm{Ti} / \mathrm{IrO}_{2}$ electrode was approximately $60 \%$. With an increase electrolysis time to $12 \mathrm{~h}$, the TN removal efficiency was $72 \%$, with a post-treatment output concentration $180 \mathrm{mg} / \mathrm{L}$, which did not meet the Vietnamese discharge standard. The study of Szpyrkowicz et al. [31] showed that the TN treatment efficiency of the Ti/Pt-Ir electrode was higher than that of the $\mathrm{Ti} / \mathrm{IrO}_{2}$ electrode. 

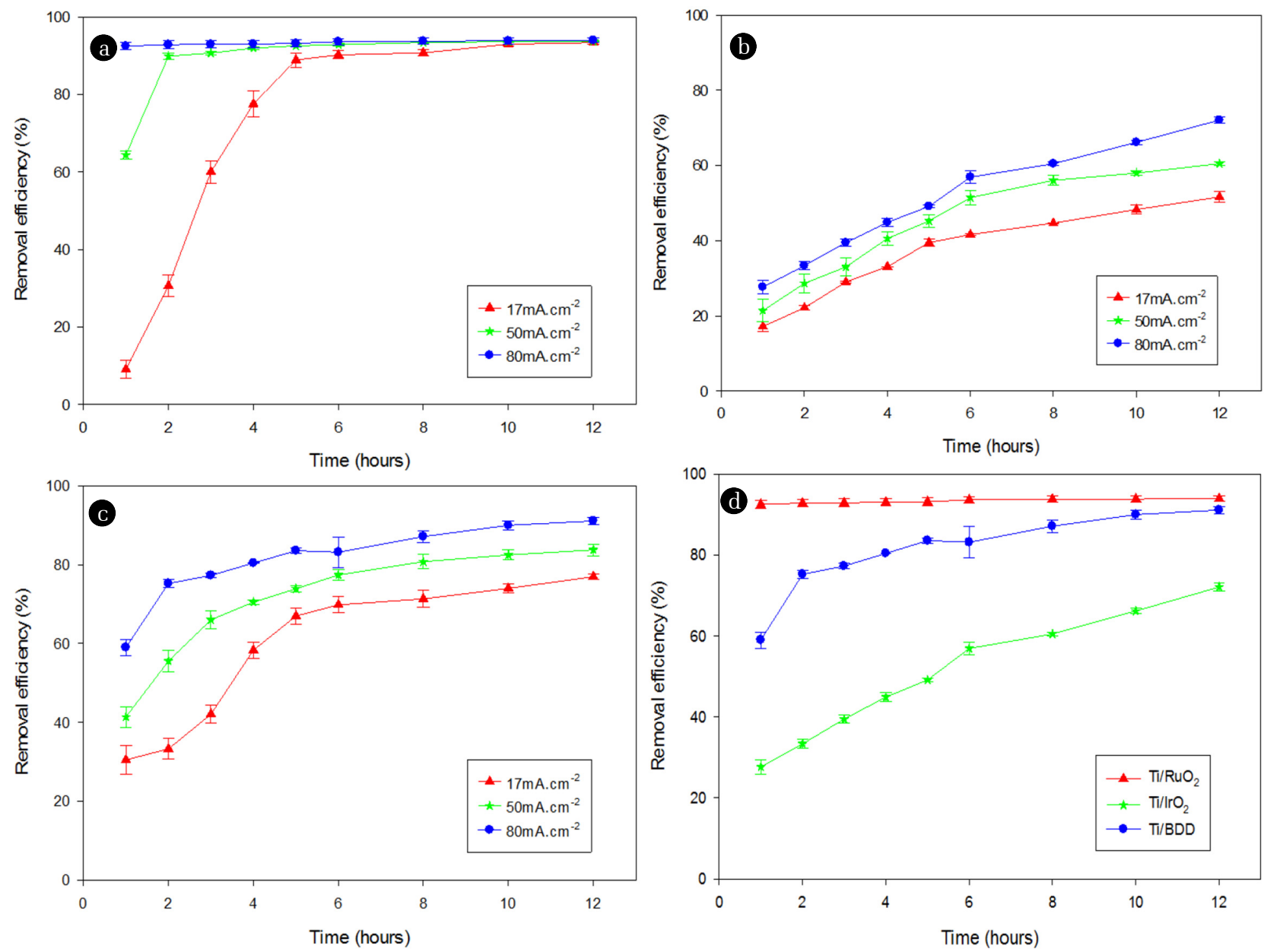

Fig. 4. $\mathrm{TN}$ removal efficiency of (a) $\mathrm{Ti} / \mathrm{RuO}_{2}$, (b) $\mathrm{Ti} / \mathrm{IrO}_{2}$, (c) $\mathrm{Ti} / \mathrm{BDD}$ electrodes at different current densities and (d) all electrodes at current density $80 \mathrm{~mA} / \mathrm{cm}^{2}$.

In that study, tannery wastewater treatment using a Ti/Pt-Ir 100 $\mathrm{cm}^{2}$ electrode, with an initial TN concentration $370 \mathrm{mg} / \mathrm{L}$ and $1 \mathrm{~h}$ of electrolysis at a current density of $40 \mathrm{~mA} / \mathrm{cm}^{2}$ gave an efficiency of $85 \%$. The author explained that the electrochemical process using a Pt-Ir mixture enhanced the chlorine evolution process, producing strong oxidizing radicals such as $\mathrm{ClO}^{-}, \mathrm{Cl}_{2}$, ${ }^{\circ} \mathrm{OH}$, which increased the oxidation efficiency of pollutants. Similar to the decomposition mechanism of nitrogen compounds by indirect oxidation by chlorine evolution reaction but the TN treatment efficiency of $\mathrm{Ti} / \mathrm{IrO}_{2}$ electrode is lower than $\mathrm{Ti} / \mathrm{RuO}_{2}$ electrode. This can be explained by the lower level of chlorine evolution efficiency at $\mathrm{Ti} / \mathrm{IrO}_{2}$ electrodes compared to $\mathrm{Ti} / \mathrm{RuO}_{2}$ electrodes [19].

As shown in Fig. 4(c) with the Ti/BDD electrode, the TN treatment efficiency was lower than with the $\mathrm{Ti} / \mathrm{RuO}_{2}$ electrode but higher than with the $\mathrm{Ti} / \mathrm{IrO}_{2}$ electrode. With a greater current density, the stronger oxidizing radicals generated may increase the efficiency of the process. However at the Ti/BDD electrodes, the maximum TN removal efficiency of $92 \%$ was observed after $12 \mathrm{~h}$ of electrolysis at a current density of $80 \mathrm{~mA} / \mathrm{cm}^{2}$, at which the output TN in tannery wastewater $53.5 \mathrm{mg} / \mathrm{L}$ had not yet reached the Vietnamese discharge standard. As discussed above, the TN content is largely eliminated by indirect oxidation by chlorine compounds, while the Ti/BDD electrode characteristic produces both direct and indirect processes with lower chlorine evolution than DSA. According to Anglada et al. [43], the ammonium removal process was low during the initial period of electrochemical oxidation processing but then increased in efficiency as the COD concentration decreased. Urtiaga et al. [44] observed the oxidation of COD and ammonium on the surface of the BDD electrode with the ammonium removal rate was lower than the COD value. There was competition between COD and nitrogen decompositions on the surface of BDD electrode. Overall, the COD removal efficiency at a $\mathrm{Ti} / \mathrm{BDD}$ electrode is higher than at the $\mathrm{Ti} / \mathrm{RuO}_{2}$ electrode.

The evidence for chlorine evolution at $\mathrm{Ti} / \mathrm{RuO}_{2}$ electrode is shown in Fig. S1, with a decrease in $\mathrm{Cl}^{-}$concentration during the reaction. Specifically, $\mathrm{Cl}^{-}$concentrations in tannery wastewater at a $\mathrm{Ti} / \mathrm{RuO}_{2}$ electrode after $6 \mathrm{~h}$ of treatment were 3,950, 1,937, $1,400 \mathrm{mg} / \mathrm{L}$, corresponding to current densities of $16.7 \mathrm{~mA} / \mathrm{cm}^{2}$, $50 \mathrm{~mA} / \mathrm{cm}^{2}, 80 \mathrm{~mA} / \mathrm{cm}^{2}$, respectively. This means that $\mathrm{Cl}^{-}$is involved in the decomposition of organic compounds and nitrogen in the wastewater and that the higher the current density, the stronger 

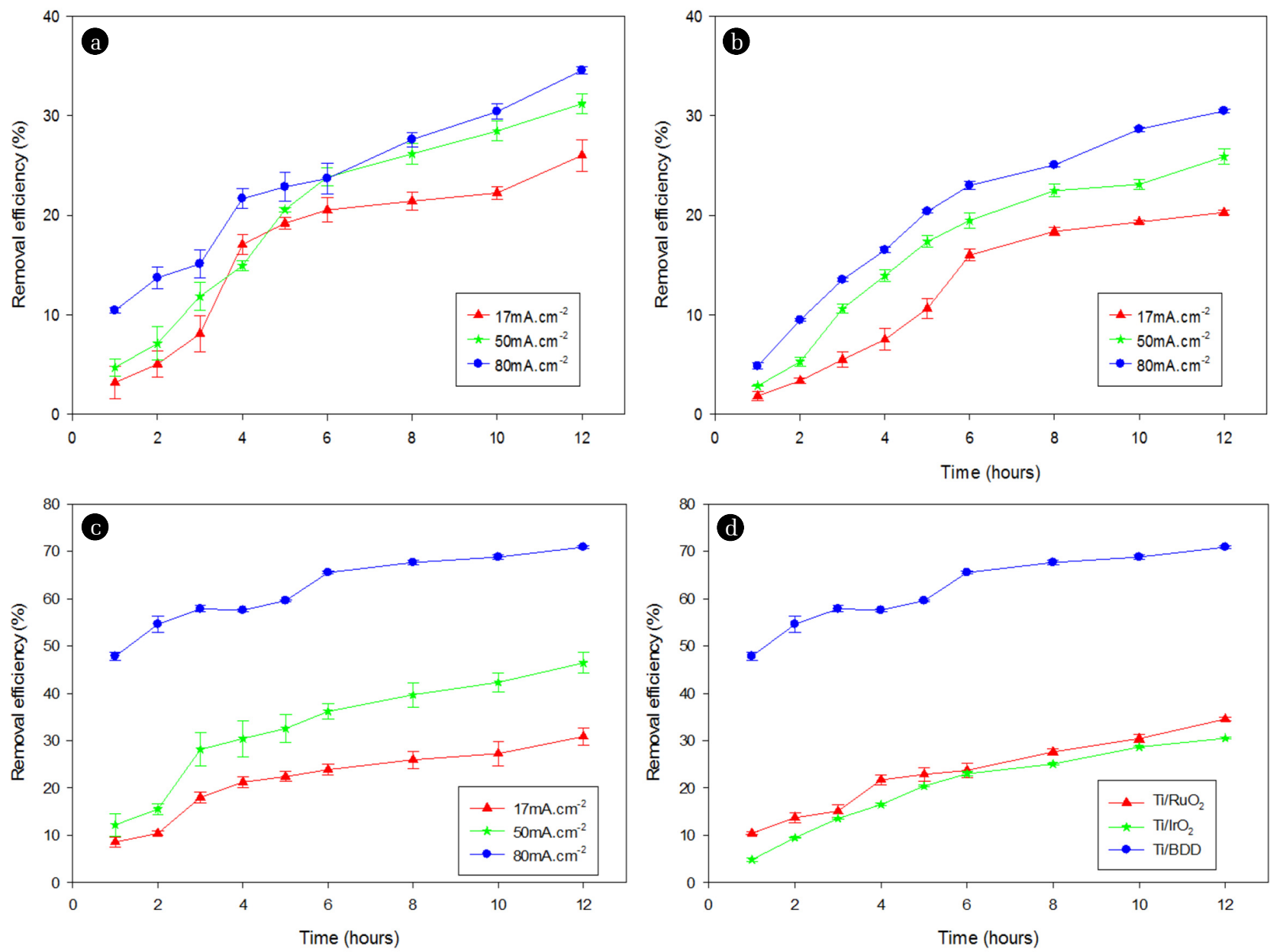

Fig. 5. TOC removal efficiency of (a) $\mathrm{Ti} / \mathrm{RuO}_{2}$, (b) $\mathrm{Ti} / \mathrm{IrO}_{2}$, (c) $\mathrm{Ti} / \mathrm{BDD}$ electrodes at different current densities and (d) all electrodes at current density $80 \mathrm{~mA} / \mathrm{cm}^{2}$.

the chloride decomposition. The electrooxidation does not only decrease the amount of pollutants, but also the salinity contamination in tannery wastewater.

\subsection{TOC Removal}

Fig. 5 shows the TOC removal efficiencies of $\mathrm{Ti} / \mathrm{RuO}_{2}, \mathrm{Ti} / \mathrm{IrO}_{2}$ and $\mathrm{Ti} / \mathrm{BDD}$ electrodes at different current densities and electrolysis times. By increasing the current density and electrolysis time, the TOC removal efficiencies were increased. As shown in Fig. $5(\mathrm{a})$, the TOC removal efficiency of the $\mathrm{Ti} / \mathrm{RuO}_{2}$ electrodes was below $40 \%$, and slightly lower at a current density of $17 \mathrm{~mA} / \mathrm{cm}^{2}$ and $50 \mathrm{~mA} / \mathrm{cm}^{2}$. The TOC removal efficiency of the $\mathrm{Ti} / \mathrm{IrO}_{2}$ electrode was lower than the $\mathrm{Ti} / \mathrm{RuO}_{2}$ electrode, with maximum $30 \%$ at current density $80 \mathrm{~mA} / \mathrm{cm}^{2}$ after $12 \mathrm{~h}$ of electrolysis as shown in Fig. 5(b). This result agrees with the report of Costa et al. [45], who also found that TOC treatment efficiency at $\mathrm{Ti} / \mathrm{Ir}_{0.01} \mathrm{Sn}_{0.99} \mathrm{O}_{2}$ electrode on tannery wastewater was below $30 \%$ with input current density $20 \mathrm{~mA} / \mathrm{cm}^{2}$ after $5 \mathrm{~h}$ of electrolysis. At current density $80 \mathrm{~mA} / \mathrm{cm}^{2}$ after $12 \mathrm{~h}$ of electrolysis, the TOC removal efficiency at the $\mathrm{Ti} / \mathrm{BDD}$ electrode was nearly $70 \%$. Ti/BDD electrodes showed superior TOC removal efficiency compared with $\mathrm{Ti} / \mathrm{RuO}_{2}$ and $\mathrm{Ti} / \mathrm{IrO}_{2}$ electrodes. This can be attributed to the generation of ${ }^{\circ} \mathrm{OH}$ at Ti/BDD electrodes, which has the main role in the mineral of organic compound. Whereas the decomposition mechanism at $\mathrm{Ti} / \mathrm{RuO}_{2}$ and $\mathrm{Ti} / \mathrm{IrO}_{2}$ electrodes is based on chlorine evolution, which is a weaker oxidation agent compare with ${ }^{\circ} \mathrm{OH}$.

\subsection{Colour Removal}

Fig. 6 shows the colour removal efficiencies of Ti/BDD, $\mathrm{Ti} / \mathrm{RuO}_{2}$ and $\mathrm{Ti} / \mathrm{IrO}_{2}$ electrodes at different current densities and electrolysis times. As shown in Fig. 6, colour removal efficiencies varied with current densities and electrolysis times. The color removal efficiencies of tannery wastewater at all 3 electrodes were high, from initial period of 1-2 h of electrolysis, yielding higher than $90 \%$ at current densities of $16.7 \mathrm{~mA} / \mathrm{cm}^{2}, 50 \mathrm{~mA} / \mathrm{cm}^{2}$ and $80 \mathrm{~mA} / \mathrm{cm}^{2}$. However, there was a tendency for decreased performance at a longer electrolysis times. For example, at the $\mathrm{Ti} / \mathrm{RuO}_{2}$ electrode, as shown in Fig. 6(a), after $12 \mathrm{~h}$ of electrolysis at current densities $16.7 \mathrm{~mA} / \mathrm{cm}^{2}, 50 \mathrm{~mA} / \mathrm{cm}^{2}, 80 \mathrm{~mA} / \mathrm{cm}^{2}$, the remaining color efficiencies were $73 \%$; $78 \%$; $87 \%$, respectively. However after 6 h of elec- 

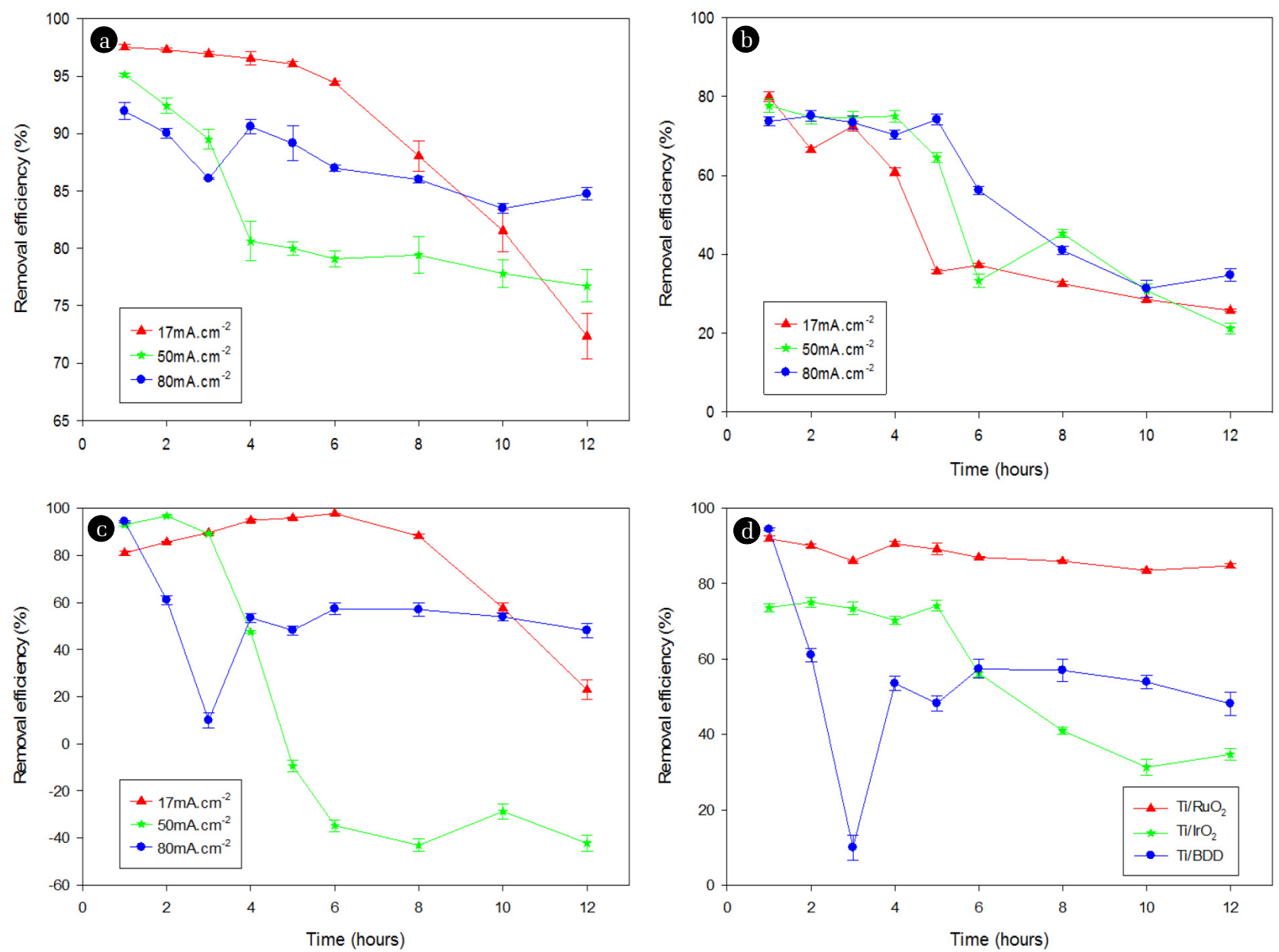

Fig. 6. Colour removal efficiency of (a) $\mathrm{Ti} / \mathrm{RuO}_{2}$, (b) $\mathrm{Ti} / \mathrm{IrO}$, (c) $\mathrm{Ti} / \mathrm{BDD}$ at different current densities and (d) all electrodes at current density $80 \mathrm{~mA} / \mathrm{cm}^{2}$.

trolysis, the smaller the current density, the higher the colour removal efficiency. This may be due to the fact that over a long period of electrolysis, by-products are created which further discolor in the output wastewater.

\subsection{Electrochemical Measurement}

Fig. 7 shows the experimental results of cyclic voltammogram monitoring of the electrochemical oxidation of tannery wastewater at $\mathrm{Ti} / \mathrm{RuO}_{2}$ and $\mathrm{Ti} / \mathrm{IrO}_{2}$ and $\mathrm{Ti} / \mathrm{BDD}$ electrodes. There were significant differences in typical cyclic voltammogram of DSA Ti/ $\mathrm{RuO}_{2}$ and $\mathrm{Ti} / \mathrm{IrO}_{2}$ electrodes, compared with $\mathrm{Ti} / \mathrm{BBD}$ electrode. With $\mathrm{Ti} / \mathrm{RuO}_{2}$ and $\mathrm{Ti} / \mathrm{IrO}_{2}$ electrodes, the onset potential at $1.3 \mathrm{~V}$ vs. $\mathrm{Ag} / \mathrm{AgCl}$ can be attributed to the oxidation peak of $\mathrm{Cl}^{-}$to $\mathrm{Cl}_{2}$, due to the high salinity concentration in the tannery wastewater. These peaks also overlap with the oxygen evolution peaks, since the onset potentials of oxygen evolution and chlorine evolution are very close. There are quite similar about the oxidants evolution mechanism at $\mathrm{Ti} / \mathrm{RuO}_{2}$ and $\mathrm{Ti} / \mathrm{IrO}_{2}$ electrodes since it belong with DSA group. The current density at the $\mathrm{Ti} / \mathrm{RuO}_{2}$ electrode was higher than at the $\mathrm{Ti} / \mathrm{IrO}_{2}$ electrode, suggesting that the chlorine evolution efficiency was higher. In another aspect, the Ti/BDD electrode had an onset potential of oxygen evolution reaction at

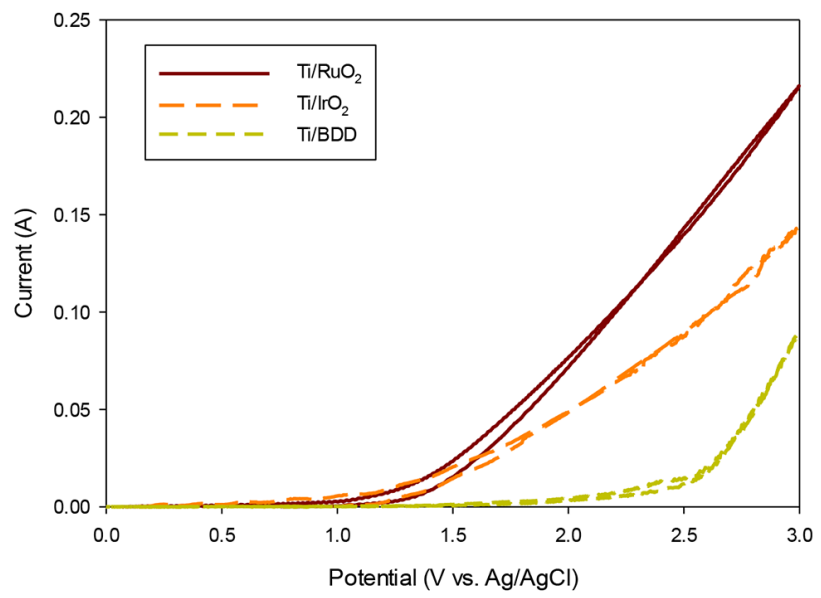

Fig. 7. Cyclic voltammogram of $\mathrm{Ti} / \mathrm{RuO}_{2}, \mathrm{Ti} / \mathrm{IrO}_{2}$ and $\mathrm{Ti} / \mathrm{BDD}$ electrodes with electrochemical tannery wastewater oxidation, scan rate $5 \mathrm{mV} / \mathrm{s}$. 

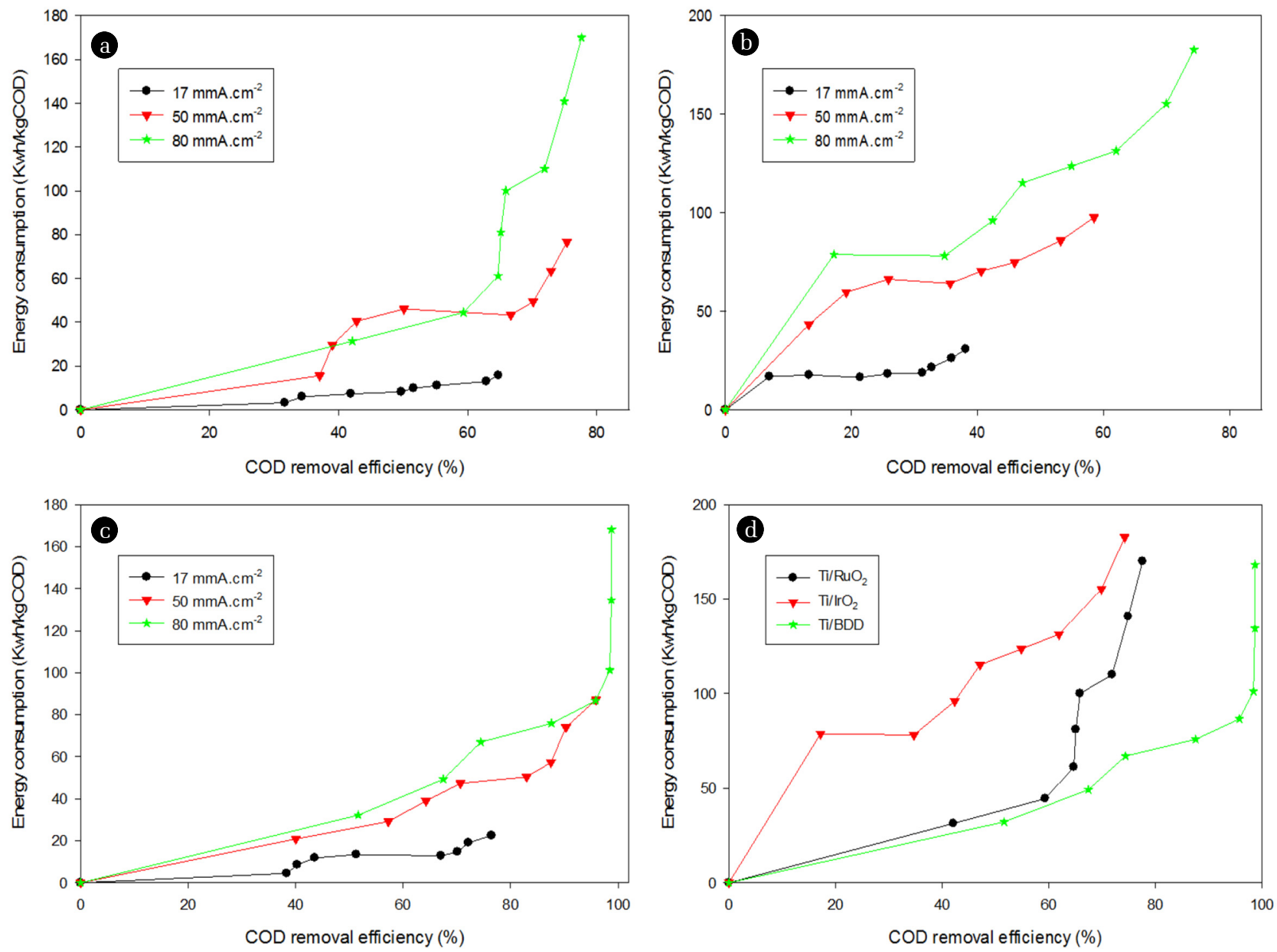

Fig. 8. Energy consumption of (a) $\mathrm{Ti} / \mathrm{RuO}_{2}$, (b) $\mathrm{Ti} / \mathrm{IrO}_{2}$, and (c) Ti/BDD electrodes, (d) All electrode at current density $80 \mathrm{~mA} / \mathrm{cm}^{2}$.

2.6 V vs. Ag/AgCl. There was one oxidation peak at $2.2 \mathrm{~V}$ vs. $\mathrm{Ag} / \mathrm{AgCl}$ which could be attributed to the oxidation peak of tannic acid at the surface of the Ti/BBD electrode [46]. This is clearly seen in Fig. 7, there is a difference about oxidant generation mechanisms at 3 electrodes. The mechanism of electrochemical oxidation at $\mathrm{DSA} \mathrm{Ti} / \mathrm{RuO}_{2}$ and $\mathrm{Ti} / \mathrm{IrO}_{2}$ electrodes is based on indirect chlorine evolution. And the direct oxidation on the electrode surface is negligible. While at Ti/BDD anode, the mechanism is mainly the direct oxidation of tannic acid on the electrode surface. Ti/BDD electrode is not so strong in the chlorine evolution reaction compared with $\mathrm{Ti} / \mathrm{RuO}_{2}$ and $\mathrm{Ti} / \mathrm{IrO}_{2}$ electrodes.

\subsection{Energy Consumption}

Fig. 8 shows the respective energy consumption of electrochemical tannery wastewater treatment using $\mathrm{Ti} / \mathrm{RuO}_{2}, \mathrm{Ti} / \mathrm{IrO}_{2}$, and $\mathrm{Ti} / \mathrm{BDD}$ electrodes. As can be seen, the energy consumption increases with the increase of current density with all 3 electrodes. The Ti/BDD electrode showed the lowest energy consumption, while the $\mathrm{Ti} / \mathrm{RuO}_{2}$ electrode was a little bit higher, and the highest energy consumption being at the $\mathrm{Ti} / \mathrm{IrO}_{2}$ electrode (Fig. 8(d)). This result shows that $\mathrm{Ti} / \mathrm{BDD}$ and $\mathrm{Ti} / \mathrm{RuO}_{2}$ electrodes are more suitable for tannery wastewater treatment, since they have the lowest energy consumption and the highest pollutant removal performances. Overall, Ti/BDD is the best electrode for industrial tannery wastewater treatment.

\section{Conclusions}

In this study, $\mathrm{DSA}{ }^{\circledR} \mathrm{Ti} / \mathrm{RuO}_{2}, \mathrm{Ti} / \mathrm{IrO}_{2}$ and $\mathrm{Ti} / \mathrm{BDD}$ electrodes were used to treat raw tannery wastewater treatment in a flow system. The results show that current density and electrolysis times strongly affect pollutant treatments. Increasing the current density and electrolysis time leads to increases in treatment efficiency, in all regards except colour. The Ti/BDD electrodes demonstrated the best levels of $\mathrm{COD}, \mathrm{BOD}_{5}$ and TOC removal efficiency and energy consumption while $\mathrm{Ti} / \mathrm{RuO}_{2}$ is better at nitrogen removal. The main pollutant mechanism in tannery wastewater treatment at a Ti/BDD electrode is based on direct oxidation on the electrode surface combined with the generation of oxidants such as ${ }^{\circ} \mathrm{OH}$ and $\mathrm{Cl}_{2}$, while the main oxidation mechanism at $\mathrm{DSA}{ }^{\circledR} \mathrm{Ti} / \mathrm{RuO}_{2}$ and $\mathrm{Ti} / \mathrm{IrO}_{2}$ electrodes is by the generation of chlorine. Electrochemical oxidation using DSA ${ }^{\circledR} \mathrm{Ti} / \mathrm{RuO}_{2}, \mathrm{Ti} / \mathrm{IrO}_{2}$ and 
Ti/BDD electrodes can be used to treat tannery wastewater to achieve the Vietnamese discharge standard for effluents after 6-12 $\mathrm{h}$ of electrolysis in a flow system.

\section{Acknowledgments}

This work is supported by the funding from Vietnamese Ministry of Education and Tranning (MOET) under the grant B2016-VGU-02 (2016-2018).

\section{References}

1. Dinh HT. Light manufacturing in Vietnam: Creating jobs and prosperity in a middle-income economy. Washington D.C.: The World Bank; 2013. p. 1-89.

2. Lofrano G, Meriç S, Zengin G, Orhon D. Chemical and biological treatment technologies for leather tannery chemicals and wastewaters: A review. Sci. Total Environ. 2013;461:265-281.

3. Deghles A, Kurt U. Treatment of raw tannery wastewater by electrocoagulation technique: Optimization of effective parameters using Taguchi method. Desal. Water Treat. 2016;57: 14798-14809.

4. Benhadji A, Ahmed MT, Maachi R. Electrocoagulation and effect of cathode materials on the removal of pollutants from tannery wastewater of Rouïba. Desalination 2011;277:128-134.

5. Song Z, Williams C, Edyvean R. Treatment of tannery wastewater by chemical coagulation. Desalination 2004;164:249-259.

6. Sengil IA, Kula S, Özacar M. Treatment of tannery liming drum wastewater by electrocoagulation. J. Hazard. Mater. 2009;167:940-946.

7. Elabbas S, Ouazzani N, Mandi L, et al. Treatment of highly concentrated tannery wastewater using electrocoagulation: Influence of the quality of aluminium used for the electrode. J. Hazard. Mater. 2016;319:69-77.

8. Suganthi V, Mahalakshmi M, Balasubramanian N. Development of hybrid membrane bioreactor for tannery effluent treatment. Desalination 2013;309:231-236.

9. Durai G, Rajasimman M, Rajamohan N. Aerobic digestion of tannery wastewater in a sequential batch reactor by salt-tolerant bacterial strains. Water Sci. Technol. 2011;1:35-40.

10. Ganesh R, Sousbie P, Torrijos M, Bernet N, Ramanujam RA. Nitrification and denitrification characteristics in a sequencing batch reactor treating tannery wastewater. CLEAN Technol. Environ. 2015;17:735-745.

11. Kargi F, Dincer AR. Use of halophilic bacteria in biological treatment of saline wastewater by fed-batch operation. Water Environ. Res. 2000;72:170-174.

12. Belkin S, Brenner A, Abeliovich A. Biological treatment of high salinity chemical industrial wastewater. Water Sci. Technol. 1993;27:105-112.

13. Woolard CR, Irvine CR. Treatment of hypersaline wastewater in sequencing batch reactor. Water Res. 1995;29:1159-1168.

14. Kargi F, Dincer AR. Biological treatment of saline wastewater by bed batch operation. J. Chem. Technol. Biotechnol. 1997;69:167-172.
15. Gregory K, Mingquan Y. Electrochemical dehalogenation of disinfection by-products and iodine-containing contrast media: A review. Environ. Eng. Res. 2018;23:345-353.

16. Khalid H, Rafid K, Nisreen J, et al. Electrocoagulation as a green technology for phosphate removal from river water. Sep. Purif. Technol. 2019;210:135-144.

17. Sire's I, Brillas E. Remediation of water pollution caused by pharmaceutical residues based on electrochemical separation and degradation technologies: A review. Environ. Int. 2012;40:212-229.

18. Peralta-Hernandez JM, Martınez-Huitle CA, Guzman-Mar JL, Ramirez AH. Recent advances in the application of electro-Fenton and photoelectro-Fenton process for removal of synthetic dyes in wastewater treatment. J. Environ. Eng. Manage. 2009;19:257-265.

19. Luu TL, Kim C, Kim S, Jiye K, Yoon J. Three dimensional macroporous $\mathrm{RuO}_{2}-\mathrm{TiO}_{2}$ electrode for chlorine evolution. Desal. Water Treat. 2017;77:94-104.

20. Luu TL, Kim J, Yoon J. Facile chemical bath deposition to fabricate $\mathrm{RuO}_{2}$ electrodes for electrochemical chlorine evolution. Desal. Water Treat. 2017;99:204-210.

21. Zhou M, Liu L, Jiao Y, Wang Q, Tan Q. Treatment of high-salinity reverse osmosis concentrate by electrochemical oxidation on BDD and DSA electrodes. Desalination 2011;277:201-206.

22. Ramjaun SN, Wang Z, Yuan R, Liu J. Can electrochemical oxidation techniques really decontaminate saline dyes wastewater? J. Environ. Chem. Eng. 2015;3:1648-1653.

23. Chen G. Electrochemical technologies in wastewater treatment. Sep. Purif. Technol. 2004;38:11-41.

24. Luu TL, Kim J, Yoon J. Microwave assisted synthesis of $\mathrm{RuO}_{2}-\mathrm{TiO}_{2}$ electrodes for chlorine evolutions. Desal. Water Treat. 2017;77:105-111.

25. APHA-AWWA-WPCF. Standard methods for the examination of water and wastewater. 17th ed. Washington D.C.; American Public Health Association; 1989.

26. Comminellis C, Nerini A. Anodic oxidation of phenol in the presence of $\mathrm{NaCl}$ for wastewater treatment. J. Appl. Electrochem. 1995;25:23-28.

27. Martínez-Huitle CA, Ferro S. Electrochemical oxidation of organic pollutants for the wastewater treatment: Direct and indirect processes. Chem. Soc. Rev. 2006;35:1324-1340.

28. Panizza M, Cerisola G. Electrochemical oxidation as a final treatment of synthetic tannery wastewater. Environ. Sci. Technol. 2004;38:5470-5475.

29. Kongjao S, Damronglerd S, Hunsom M. Simultaneous removal of chromium and organic pollutants in tannery wastewater by electroprecipitation technique. Korean J. Chem. Eng. 2007;24:730-735.

30. Szpyrkowicz L, Cherbanski R, Kelsall GH. Hydrodynamic effects on the performance of an electrochemical reactor for destruction of disperse dyes. Ind. Eng. Chem. Res. 2005;44: 2058-2068.

31. Szpyrkowic L, Kaul S, Neti RN. Tannery wastewater treatment by electro-oxidation coupled with a biological process. J. Appl. Electrochem. 2005;35:381-390.

32. Chávez EI, Rosaa C, Godínez LA, Brillas E, Hernández J. Comparative study of electrochemical water treatment proc- 
esses for a tannery wastewater effluent. J. Electroanal. Chem. 2013;173:62-69.

33. Costa CR, Botta CMR, Espindola E, Olivi P. Electrochemical treatment of tannery wastewater using DSA® electrodes. J. Hazard. Mater. 2008;153:616-627.

34. Costa CR, Olivi P. Effect of chloride concentration on the electrochemical treatment of a synthetic tannery wastewater. Electrochim. Acta 2009;54:2046-2062.

35. Randazzoa S, Scialdone O, Brillas E, Sirés I. Comparative electrochemical treatments of two chlorinated aliphatic hydrocarbons. Time course of the main reaction by-products. J. Hazard. Mater. 2011;192:1555-1564.

36. Kapałka A. Kinetic modelling of the electrochemical mineralization of organic pollutants for wastewater treatment. J. Appl. Electrochem. 2008;38:7-16.

37. Chang M, Gao C, Jiang J. Electrochemical oxidation of organic compounds using boron-doped diamond electrode. J. Electrochem. Soc. 2009;156:E50-E54.

38. Mandal P, Dubey BK, Gupta AK. Review on landfill leachate treatment by electrochemical oxidation: Drawbacks, challenges and future scope. Waste Manage. 2017;69:250-273.

39. Chiang L, Chang J, Wen T. Indirect oxidation effect in electrochemical oxidation treatment of landfill leachate. Water Res.
1995;29:671-678.

40. Gendel Y, Lahav O. Revealing the mechanism of indirect ammonia electrooxidation. Electrochim. Acta 2012;63:209-219.

41. Zhou B, Yu Z, Wei Q, Long H, Xie Y, Wang Y. Electrochemical oxidation of biological pretreated and membrane separated landfill leachate concentrates on boron doped diamond anode. Appl. Surf. Sci. 2016;377:406-415.

42. Min K, Yu J, Kim Y, Yun Z. Removal of ammonium from tannery wastewater by electrochemical treatment. J. Environ. Sci. Health A. 2006;39:1867-1897.

43. Anglada A, Urtiaga A, Ortiz I. Laboratory and pilot plant scale study on the electrochemical oxidation of landfill leachate. J. Hazard. Mater. 2010;181:729-735.

44. Urtiaga A, Rueda A, Anglada A, Ortiz I. Integrated treatment of landfill leachates including electrooxidation at pilot plant scale. J. Hazard. Mater. 2009;166:1530-1534.

45. Costa CR, Montilla F, Morallón E, Olivia P. Electrochemical oxidation of synthetic tannery wastewater in chloride-free aqueous media. J. Hazard. Mater. 2010;180:429-435.

46. Szpyrkowicz L, Kaul SN, Neti RN, Satyanarayan S. Influence of anode material on electrochemical oxidation for the treatment of tannery wastewater. Water Res. 2005;39:1601-1613. 